\title{
Sandro Manfroni, «La "donna-Anima" in un personaggio di Honoré de Balzac»
}

\section{Marco Stupazzoni}

\section{(2) OpenEdition}

1 Journals

\section{Edizione digitale}

URL: https://journals.openedition.org/studifrancesi/26512

DOI: 10.4000/studifrancesi.26512

ISSN: 2421-5856

\section{Editore}

Rosenberg \& Sellier

\section{Edizione cartacea}

Data di pubblicazione: 1 avril 2007

Paginazione: 193

ISSN: 0039-2944

\section{Notizia bibliografica digitale}

Marco Stupazzoni, «Sandro Manfroni, «La "donna-Anima" in un personaggio di Honoré de Balzac»»,

Studi Francesi [Online], 151 (LI | I) | 2007, online dal 30 novembre 2015, consultato il 23 novembre 2021. URL: http://journals.openedition.org/studifrancesi/26512 ; DOI: https://doi.org/10.4000/ studifrancesi.26512

\section{Questo documento è stato generato automaticamente il 23 novembre 2021.}

\section{(c) (1)}

Studi Francesi è distribuita con Licenza Creative Commons Attribuzione - Non commerciale - Non opere derivate 4.0 Internazionale. 


\title{
Sandro Manfroni, «La "donna- Anima" in un personaggio di Honoré de Balzac»
}

\author{
Marco Stupazzoni
}

\section{NOTIZIA}

SANDRO MANFRONI, «La "donna-Anima" in un personaggio di Honoré de Balzac», in «Studi junghiani», vol. 10, n. 2, luglio-dicembre 2004, pp. 79-93.

1 Secondo Sandro Mafroni, Le Médecin de campagne di Balzac si annovera tra quei testi letterari che, in misura diversa, costituiscono «vere e proprie anticipazioni di concetti successivamente formulati [...] dalla dottrina psicoanalitica e dalla psicologia juglandacée» (p. 79). È, in particolare, nell'opposizione tra i concetti di Persona e di Anima che la teoria di Jung individua quel complesso sistema di relazioni tra coscienza individuale, inconscio e proiezione sociale (o esterna) della coscienza stessa. Nel romanzo balzachiano, questa dicotomia tra Persona e Anima troverebbe la sua personificazione letteraria nella figura del dottor Benassis e in quella della Fosseuse (la donna-Anima) e configurerebbe allo stesso tempo la tormentata situazione tipica dell'artista e del suo mondo interiore. 